\title{
Apparent digestible phosphorus in the feeding of pigs in relation to availability, requirement and environment. 2. The requirement of digestible phosphorus for piglets, growing-finishing pigs and breeding sows
}

\author{
A. W. JONGBLOED \& H. EVERTS \\ DLO-Research Institute for Livestock Feeding and Nutrition, P.O. Box 160, NL 8200 AD \\ Lelystad, Netherlands
}

Received 4 April 1991; accepted 21 February 1992

\begin{abstract}
The supply of $\mathrm{P}$ with the feed should not exceed the animals requirement too much for environmental reasons. Therefore in addition to knowledge on the digestibility of $\mathrm{P}$ in feedstuffs one needs data on the animal's requirement for $P$.

The requirement for digestible $P$ for maintenance, growth, foetal growth and milk production of pigs was estimated based on the factorial approach. With this approach, recommendations of digestible $\mathrm{P}$ were formulated for several categories of pigs and types of production. For piglets from $10-20 \mathrm{~kg}$, growing pigs from $30-50 \mathrm{~kg}$, finishing pigs from $50 \mathrm{~kg}$ onwards, pregnant and lactating sows, 3.6, 2.3, 2.0, 2.2 and $2.9 \mathrm{~g}^{\text {digestible }} \mathrm{P} \mathrm{kg}^{-1}$ feed, respectively, is recommended. Large differences in recommendations of the $P$ requirements exist between those reported in the literature and our calculations. Those for piglets in the literature were higher compared to our data. For sows further information concerning the $\mathrm{P}$ requirement in different phases of pregnancy and lactation is required to allow a more precise estimation of the $P$ requirement.
\end{abstract}

Keywords : pigs, sows, digestibility, phosphorus, requirement

\section{Introduction}

To reduce the excretion of phosphorus one needs in addition to knowledge on the digestibility of $\mathrm{P}$ in feedstuffs also data on the requirement for $\mathrm{P}$ of animals at any stage and type of production. Current recommendations for $\mathrm{P}$ requirements of pigs vary widely in different countries (ARC, 1981; NRC, 1988; DLG, 1987). The reason for this is likely to be due to differences in housing, genotype, level of feeding, major ingredients used in and energy content of the diets and criteria of adequacy.

The methods used to estimate $\mathrm{P}$ requirement of pigs have been fully discussed (ARC, 1981; Guéguen \& Perez, 1981; NRC, 1988). Two approaches for estimating $P$ requirements have been described, the empirical approaches (balance or 
feeding experiments) and the factorial approach. The advantages and disadvantages of both methods have been extensively discussed (Jongbloed, 1987). Scientifically the factorial method is considered to be advantageous for several reasons, not least that it allows a more accurate approach because it can be applied to various systems of production. However, requirement figures deduced with the factorial approach need approval in feeding experiments.

The factorial method relies on the amount of endogenous $P$ excreted in faeces and urine (maintenance) as well as knowledge of the content of $P$ in weight gain or growth and in maternal and foetal tissue or milk. The maintenance requirement of $\mathrm{P}$ is expressed as $\mathrm{g} \mathrm{P} \mathrm{kg}{ }^{-1}$ live weight $\mathrm{day}^{-1}$. The requirement of $\mathrm{P}$ for production is expressed as $\mathrm{g} \mathrm{P} \mathrm{kg}^{-1}$ growth for growing pigs, and as $\mathrm{g} \mathrm{P}$ day $^{-1}$ for pregnant and lactating sows.

In the literature (ARC, 1981; NRC, 1988) there is a consensus about the requirement of available $\mathbf{P}$ for maintenance and production, but differences arise when the requirement is expressed as a dietary concentration. To be able to balance $\mathrm{P}$ concentrations in the diet according to requirements, the availability or digestibility of $P$ within the feed used must be known. Until recently this has not been possible, due to lack of sufficiently reliable digestibility figures of $P$. This problem can now be overcome, by using the data on digestibility of $\mathrm{P}$ in feedstuffs of Jongbloed \& Kemme (1990).

As Ca absorption and utilization has a close relationship with $\mathrm{P}$ absorption and utilization also some attention is paid to the $\mathrm{Ca}$ requirement. From the studies of Jongbloed (1987) a ratio of Ca to digestible P between 2.9 and 3.5 was suggested. This ratio is applied to the data on digestible $\mathrm{P}$ in this study. However, a recent study shows that this ratio may be too high resulting in a lowered $\mathrm{P}$ digestibility of the feed (Jongbloed, unpublished). As a consequence the $\mathrm{P}$ requirement is enhanced.

Our aim is to provide information on the requirement of digestible phosphorus for piglets, growing-finishing pigs and breeding sows. Therefore an extensive study of the literature was performed. The data from the literature were supplied with data from own research and various statistical calculations were done to estimate requirements of $\mathbf{P}$ for maintenance, growth, foetal growth and milk production.

\section{Maintenance requirement for $P$}

The maintenance requirement for $\mathrm{P}$ is determined by the loss of endogenous $\mathrm{P}$ in faeces and the loss of $\mathrm{P}$ in urine. By expressing the requirement in terms of apparent digestible $\mathbf{P}$ one has to realize that the contribution of endogenous faecal excretion is already taken into account. Therefore, maintenance requirement of apparent digestible $\mathbf{P}$ equals urinary loss. Excretion of $\mathbf{P}$ in urine is highly correlated with its dietary supply due to homeostatic mechanisms. Jongbloed (1987) showed that, at low dietary $\mathrm{P}$ levels and $\mathrm{Ca}: \mathrm{P}$ ratios ranging from $1.0: 1$ to $2.0: 1$, $20 \mathrm{mg} \mathrm{P}$ day $^{-1}$ was excreted in the urine of pigs weighing $30 \mathrm{~kg}$, whereas $40 \mathrm{mg}$ $\mathrm{P}$ day $^{-1}$ was recorded for pigs weighing $100 \mathrm{~kg}$. This amounts to between 0.7 and $0.4 \mathrm{mg} \mathrm{P} \mathrm{kg}^{-1}$ live weight day ${ }^{-1}$. Similar values were also reported in studies of 
Grimbergen et al. (1985) and Pointillart et al. (1985). In breeding sows, urinary losses of $P$ are also low. In experiments at Lelystad they ranged from 0.10 to 0.15 $\mathrm{g} \mathrm{P}$ day $^{-1}$ when low dietary P levels were used up to $0.6 \mathrm{~g}_{\text {day }}{ }^{-1}$ with high levels of $\mathrm{P}$ in the diets. At low levels of dietary $\mathrm{P}$, both for growing pigs and breeding sows the urinary excretion of $\mathrm{P}$ in the urine amounts to about $1 \mathrm{mg} \mathrm{P} \mathrm{g^{-1 }}$ live weight day ${ }^{-1}$. This figure is used for further calculations.

Jongbloed (1987) undertook an extensive survey of the estimates of endogenous excretion of $\mathrm{P}$ in faeces, from which it was concluded that the amount of faecal endogenous loss of $\mathrm{P}$ was low and to some extent depended on the level of supply (Table 1). The amount of endogenous $P$ loss was lower at deficient dietary levels of $P$. We assume that, for growing pigs at a dietary supply of $P$ above $5.8 \mathrm{~g} \mathrm{~kg}^{-1}$ $\mathrm{DM}$ on average, $9 \mathrm{mg}$ of endogenous $\mathrm{P} \mathrm{kg}^{-1}$ live weight day ${ }^{-1}$ is excreted in faeces. For breeding sows at a live weight above $140 \mathrm{~kg}$ the mean daily endogenous loss of $\mathrm{P}$ in faeces was $4.5 \mathrm{mg} \mathrm{kg} \mathrm{g}^{-1}$ live weight (Table 1). However, only three observations were obtained for sows on $\mathbf{P}$ free diets and only two observations were available for lactating sows. Therefore data for breeding sows are not well established.

It is known from the literature (Vemmer, 1982; Jongbloed, 1987), that the absorption coefficient of $P$ is lower when a surplus of $P$ is offered in relation to requirement. This means that in practice, where animals are mostly fed above their requirement, the digestibility of $\mathrm{P}$ will be somewhat lower than that obtained in our experiments (Jongbloed and Kemme, 1990). In our experiments with growing pigs used to assess the digestibility of $\mathrm{P}$, the concentration of $\mathrm{P}$ in the diets was mostly between 4 and $6 \mathrm{~g} \mathrm{~kg}^{-1} \mathrm{DM}$, which was supposed to supply a minimum amount of digestible $\mathrm{P}$. To compensate for the lower digestibility of $\mathrm{P}$, when animals are fed above their requirement, it is suggested that instead of lowering the digestibility of $\mathrm{P}$ in feedstuffs it is prefered to increase the maintenance requirement of digestible $P$, being the difference in faecal endogenous excretion between a low and adequate dietary supply of $P$ which is $6 \mathrm{mg} \mathrm{kg}^{-1}$ live weight. This amount together with the urinary loss of $1 \mathrm{mg} \mathrm{kg}^{-1}$ live weight is used as 'endogenous loss' both for growing pigs and breeding sows and can be regarded as a compensation and safety margin. As no recent data are available concerning faecal endogenous loss of $\mathrm{P}$ it can be recommended to obtain more data.

Table 1. Daily loss of endogenous $P$ in faeces of pigs (after Jongbloed 1987).

\begin{tabular}{lccl}
\hline Live weight range $(\mathrm{kg})$ & $\begin{array}{l}\text { Number of experi- } \\
\text { ments }\end{array}$ & $\begin{array}{l}\text { Range of } \mathrm{P} \text { contents } \\
\text { in diet }\left(\mathrm{g} \mathrm{kg}^{-1} \mathrm{DM}\right)\end{array}$ & $\begin{array}{l}\text { Mean (and range) of } \\
\text { endogenous faecal P } \\
\text { loss }\left(\mathrm{mg} \mathrm{kg}^{-1} \text { live }\right. \\
\text { weight) }\end{array}$ \\
$15-80$ & 11 & $0-3.3$ & $2.9(1.3-4.8)$ \\
$14-80$ & 8 & $5.8-8.3$ & $8.8(1.8-17.6)$ \\
$>140$ & 8 & $0-6.3$ & $4.5(3.0-7.1)$ \\
\hline
\end{tabular}




\section{The requirement of $\mathbf{P}$ for growth}

The $\mathbf{P}$ requirement for growth can be best estimated by data obtained using the slaughter technique, because in most balance experiments the retention of $P$ is overestimated (Jongbloed, 1987). From our earlier studies it was concluded by means of an allometric function that the requirement for growth is on average 5.1 $\mathrm{g} \mathrm{P} \mathrm{kg}^{-1}$ live weight gain (Jongbloed, 1987). This function was $\ln \mathrm{P}(\mathrm{g})=1.628$ $+1.000 \ln \mathrm{W} ; \mathrm{W}=$ live weight $(\mathrm{kg})$ and was based on 53 data from the literature and own experiments. There was a small non-significant quadratic effect, indicating a higher amount of $\mathrm{P} \mathrm{kg}^{-1}$. live weight gain at lower weights. The diets used for the calculations contained a high concentration of $\mathrm{P}$ and $\mathrm{Ca}$, so it may be assumed that almost maximal bone calcification occurred, although for optimal performance this is not required (NRC, 1988; Guéguen \& Perez, 1981). In studying the $\mathrm{P}$ requirement for growth, two types of growth were distinguished, normal and very lean (Jongbloed, 1987). The normal type is a pig having a meat percentage in the carcass at slaughter of less than 54, while in a lean type of pig that is more than 55. Although there was a non-significant quadratic effect it was decided to take the quadratic effect into account when calculating requirements, because a quadratic effect is more in agreement with the concept of growth models and because there was a significant quadratic effect when empty body weight was used as independent variable. The function with the quadratic term for live weight was: $\ln P=1.494+1.108 \ln \mathrm{W}-0.018(\operatorname{ln~W})^{2}$. The results of these calculations are presented in Table 2, and indicate higher requirements (about $0.25 \mathrm{~g} \mathrm{~kg}^{-1}$ body weight gain) for very lean than normal pig types (Jongbloed, 1987).

The value of $5.4 \mathrm{~g} \mathrm{P} \mathrm{kg}^{-1}$ live weight gain for pigs from 10 to $20 \mathrm{~kg}$ is markedly lower than those proposed by Guéguen \& Perez (1981) and ARC (1981), who suggested that from 10 to $20 \mathrm{~kg}$ the $P$ requirement for growth amounted 6.5 and $8.5 \mathrm{~g} \mathrm{P} \mathrm{kg}^{-1}$ live weight, respectively. However, in more recent studies at the IVVO with piglets weaned at 25 and 31 days of age, weighing about 8 and 11.5 $\mathrm{kg}$ resp., a value of 4.9 to $5.0 \mathrm{~g} \mathrm{P} \mathrm{kg}^{-1}$ live weight gain was again found (Dellaert et al., 1990). Differences between these values for young pigs and those adopted by Guéguen \& Perez (1981) and ARC (1981) may be attributable in part to genetic factors, but there is also likely to be a large element of over estimation of

Table 2. Calculated requirement of digestible $P$ for growth $\left(\mathrm{g} \mathrm{kg}^{-1}\right.$ live weight gain) in pigs (Jongbloed, 1987).

Pig type

Live weight $(\mathrm{kg})$

\begin{tabular}{lllllllll} 
& 10 & 30 & 50 & 60 & 70 & 90 & 110 \\
& & & & & & & & \\
Normal & - & 5.10 & 4.94 & 4.87 & 4.80 & 4.70 & 4.60 \\
Very lean & 5.45 & 5.35 & 5.19 & 5.12 & 5.05 & 4.95 & 4.85 & \\
\hline
\end{tabular}


amount of $\mathbf{P}$ in this type of animal. The highest values we found in the literature for 10 to $20 \mathrm{~kg}$ pigs were 5.7 and $5.6 \mathrm{~g} \mathrm{P} \mathrm{kg}^{-1}$ gain day ${ }^{-1}$ respectively (Mudd et al.,1969a; Møllgaard, 1955). However, for pigs from $25 \mathrm{~kg}$ live weight onwards there are no major differences between our values and those in the literature, except for the values of ARC (1981) for pigs over $80 \mathrm{~kg}$ live weight. ARC (1981) using a polynomial model estimated a $\mathrm{P}$ requirement for growth of a $90 \mathrm{~kg}$ pig of only $1.0 \mathrm{~g} \mathrm{~kg}^{-1}$ empty body weight gain.

In Table 3 the results are presented of our calculations concerning the requirement for $\mathrm{P}$ of young pigs. It is assumed that the average daily gain is $450 \mathrm{~g}$ and the feed intake between 4.5 and $5.0 \%$ of the live weight in the weight range from 10 to $25 \mathrm{~kg}$. In addition calculations are also presented in Table 3 for pigs of $5 \mathrm{~kg}$ live weight. The figures in this table suggest that for weaned piglets a concentration of $3.7 \mathrm{~g} \mathrm{P} \mathrm{kg}^{-1}$ will suffice.

The data shown in Table 4 indicate the estimated requirement of digestible $\mathrm{P}$ for growing pigs from 30 to $110 \mathrm{~kg}$ live weight. The calculations are based on a mean growth rate of $780 \mathrm{~g} \mathrm{day}^{-1}$ and a feed conversion ratio of $3.0(\mathrm{CVB}, 1990)$. The required concentration of digestible $\mathrm{P}$ in the feed gradually decreases from 2.3 to $1.5 \mathrm{~g} \mathrm{~kg}^{-1}$ as the weight of the animal increases from 30 to $110 \mathrm{~kg}$.

To our opinion for a very lean pig type the concentration of digestible $\mathrm{P}$ should be increased by $0.1 \mathrm{~g} \mathrm{~kg}^{-1}$. At a mean growth rate of $900 \mathrm{~g} \mathrm{day}^{-1}$ and a feed conversion ratio of 2.5 it can be calculated that the concentration of digestible $P$ should be from 0.4 to $0.5 \mathrm{~g} \mathrm{~kg}^{-1}$ higher than presented in Table 4 (Jongbloed, 1987).

\section{The requirement of $P$ for foetal growth and maternal tissue}

In the first two months of gestation the requirement of pregnancy for $\mathrm{P}$ is low. In that period $\mathrm{P}$ is mainly used for restoring body reserves (protein and fat) lost during the last lactation period. In contrast to fat, protein deposition is partly related to the $P$ supply ( $P$ concentration in protein is $60 \mathrm{~g} \mathrm{~kg}^{-1} \mathrm{~N}$; Jongbloed, 1987). Balance studies at Lelystad show that about $10 \mathrm{~g} \mathrm{~N}$ day $^{-1}$ is deposited in the middle of pregnancy, which is almost completely used for maternal tissue (udder and uterus not included). The deposition of $\mathrm{N}$ for restoring protein reserves seems to decline gradually during the second phase of pregnancy. Den Hartog et al. (1988) demonstrated a gradual increase in weight of placenta during pregnancy from 1900 to $3800 \mathrm{~g}$ measured on day 60 and 112 , respectively. They presented no data on the weight of uterus. In our own studies a total average weight of uterus, placenta and allantoic fluids of $8.1 \mathrm{~kg}$ at day 110 of pregnancy was observed. The concentration in this material was $0.7 \mathrm{~g} \mathrm{P} \mathrm{kg}^{-1}\left(5.7 \mathrm{~g} \mathrm{P}^{\text {in }}\right.$ total). Assuming the same development in the course of gestation for the uterus as for the placenta, then the daily increase of $P$ is $0.05 \mathrm{~g}$. The daily increase of $P$ in the udder was $0.1 \mathrm{~g}$ from day 87 to day 102 and thereafter it was $0.5 \mathrm{~g} \mathrm{P}$ (Den Hartog et al., 1988).

Provision of $\mathrm{P}$ or $\mathrm{Ca}$ in the diet for pregnant sows reflects on the extent of bone growth and bone mineralization and extra uterine growth during pregnancy and 


\section{A. W. JONGBLOED AND H. EVERTS}

Table 3. Estimated requirement of digestible $\mathrm{P}$ for piglets up to $25 \mathrm{~kg}$.

\begin{tabular}{|c|c|c|c|c|c|c|}
\hline \multirow[b]{2}{*}{$\begin{array}{l}\text { Live } \\
\text { weight } \\
(\mathrm{kg})\end{array}$} & \multirow[b]{2}{*}{$\begin{array}{l}\text { Growth } \\
\left(\mathrm{g} \mathrm{day}^{-1}\right)\end{array}$} & \multicolumn{5}{|c|}{ Requirement of digestible $\mathrm{P}$} \\
\hline & & $\begin{array}{l}\text { for 'maintenance' } \\
\left(\mathrm{g} \mathrm{day}^{-1}\right)\end{array}$ & $\begin{array}{l}\text { for growth } \\
\left(\mathrm{g} \text { day }^{-1}\right)\end{array}$ & $\begin{array}{l}\text { total } \\
(\mathrm{g} \mathrm{dig.} \mathrm{P} \\
\left.\text { day }^{-1}\right)\end{array}$ & $\begin{array}{l}\text { feed } \\
\text { intake } \\
\left(\mathrm{kg}^{-1}\right) \\
\left.\text { day }^{-1}\right)\end{array}$ & $\begin{array}{l}\text { in diet }{ }^{1} \\
(\mathrm{~g} \text { dig.P } \\
\left.\mathrm{kg}^{-1}\right)\end{array}$ \\
\hline 5 & 200 & 0.04 & 1.09 & 1.13 & 0.24 & 4.7 \\
\hline 10 & 300 & 0.07 & 1.64 & 1.71 & 0.48 & 3.7 \\
\hline 15 & 450 & 0.11 & 2.45 & 2.56 & 0.71 & 3.6 \\
\hline 20 & 620 & 0.14 & 3.38 & 3.83 & 0.95 & 3.7 \\
\hline 25 & 670 & 0.18 & 3.65 & 3.81 & 1.19 & 3.2 \\
\hline
\end{tabular}

${ }^{1}$ The feed contains $9.7 \mathrm{MJ} \mathrm{NE}_{\mathrm{f}}$ or $13.8 \mathrm{MJ} \mathrm{ME} \mathrm{kg}{ }^{-1}$.

Table 4. Estimated requirement of apparent digestible $\mathrm{P}$ for growing pigs.

\begin{tabular}{|c|c|c|c|c|c|c|}
\hline \multirow[b]{2}{*}{$\begin{array}{l}\text { Live } \\
\text { weight } \\
\text { (kg) }\end{array}$} & \multirow[b]{2}{*}{$\begin{array}{l}\text { Growth } \\
\left(\text { g day }^{-1}\right)\end{array}$} & \multicolumn{5}{|c|}{ Requirement of digestible $P$} \\
\hline & & $\begin{array}{l}\text { 'Maintenance' } \\
\left(\mathrm{g} \mathrm{day}^{-1}\right)\end{array}$ & $\begin{array}{l}\text { growth }^{\mathrm{a}} \\
\left(\mathrm{g} \mathrm{day}^{-1}\right)\end{array}$ & $\begin{array}{l}\text { total } \\
\left(\mathrm{g} \mathrm{day}^{-1}\right)\end{array}$ & $\begin{array}{l}\text { feed intake } \\
\left(\mathrm{kg} \mathrm{day}^{-1}\right)\end{array}$ & $\begin{array}{l}\mathrm{P} \text { content of feed } \\
(\mathrm{g} \text { dig. } \mathrm{P} \mathrm{kg} \text { ) }\end{array}$ \\
\hline 30 & 570 & 0.21 & 2.91 & 3.12 & 1.35 & 2.3 \\
\hline 50 & 820 & 0.35 & 4.05 & 4.40 & 2.15 & 2.0 \\
\hline 70 & 865 & 0.49 & 4.15 & 4.64 & 2.75 & 1.7 \\
\hline 90 & 875 & 0.63 & 4.11 & 4.74 & 3.05 & 1.6 \\
\hline 110 & 855 & 0.77 & 3.93 & 4.70 & 3.10 & 1.5 \\
\hline
\end{tabular}

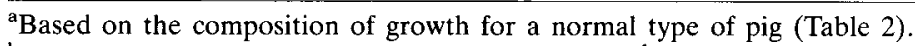

${ }^{\mathrm{b}}$ Feed contains $9.05 \mathrm{MJ}$ NEf or $12.9 \mathrm{~g} \mathrm{MJ} \mathrm{ME} \mathrm{kg}{ }^{-1}$.

the subsequent possible demineralization during lactation. Sows fed deficient levels of $\mathrm{P}$ and $\mathrm{Ca}$ during lactation are expected to resorb partly from their bones during lactation. We assume that $1 \mathrm{~g} \mathrm{P}$ daily is required for accretion of $\mathrm{P}$ in bones due to growth of the skeleton and possible compensation for demineralization during lactation. Mineralization in foetuses predominantly takes place in the last month of pregnancy (Becker, 1976; Den Hartog et al., 1988). From their slaughter experiments Den Hartog et al. (1988) concluded that the live weight of a foetus (y) could be estimated by Equation 1

$$
y(g)=8.58 \times 10^{-6} \times t^{4}
$$

where $\mathrm{t}=$ days of pregnancy.

Our data obtained with foetuses at 110 days of pregnancy fit quite well in Equation 1. Together with Equation 2 which is used for estimating the concen- 
tration of $\mathrm{P}$ per $\mathrm{kg}$ foetus the amount of $\mathrm{P}$ can be estimated. These appropriate values for different stages of pregnancy are given in Figure 1.

$$
\mathrm{P}\left(\mathrm{g} \mathrm{kg}^{-1}\right)=-0.82+0.058 \times \mathrm{t}
$$

where $\mathrm{t}=$ days of pregnancy.

Calculations presented in Table 5 were performed for 12 piglets with a birth weight of $1500 \mathrm{~g}$.

In the case of nulliparous sows the elements for estimation of the requirement of $P$ are somewhat different from multiparous sows. The increase of maternal tissue (udder and uterus not included) of nulliparous sows is mostly from about 120 (at mating) to $160 \mathrm{~kg}$. In that period it is still a growing animal with a considerable increase of body protein and bone tissue. From own studies, using diets with a $\mathrm{P}$ supply far above $\mathrm{P}$ requirement, an increase of $230 \mathrm{~g} \mathrm{P}$ was observed in that period, which is $2.0 \mathrm{~g} \mathrm{P}$ day $^{-1}$. This amount includes $0.6 \mathrm{~g} \mathrm{P}$ as extra protein growth. Based on these data it can be concluded that $1.4 \mathrm{~g} \mathrm{P} \mathrm{day}^{-1}$ is retained in bone tissue, which is $0.4 \mathrm{~g} \mathrm{P}$ higher than indicated in Table 5. However, this 0.4 $\mathrm{g} P$ can be compensated when taking into consideration a $60 \mathrm{~kg}$ lower live weight than the $200 \mathrm{~kg}$ adopted in Table 5 , resulting in $0.4 \mathrm{~g}$ P less for maintenance, and a lower number of piglets born for nulliparous sows. The average increase in $P$ amount in the body of sows from the first lactation to the end of the third lactation was $0.5 \mathrm{~g} \mathrm{day}^{-1}$, which is substantially lower than the sum of accretion of $\mathrm{P}$ in bones and extra uterine growth given in Table 5. However, the amount of $0.5 \mathrm{~g}$ day $^{-1}$ had a large standard deviation $(100 \%)$. On the other hand if a litter is born of more than 12 piglets then the surplus of digestible $\mathrm{P}$ in the feed can be used for this. Therefore the total requirement of $P$ for nulliparous and multiparous sows is almost the same.

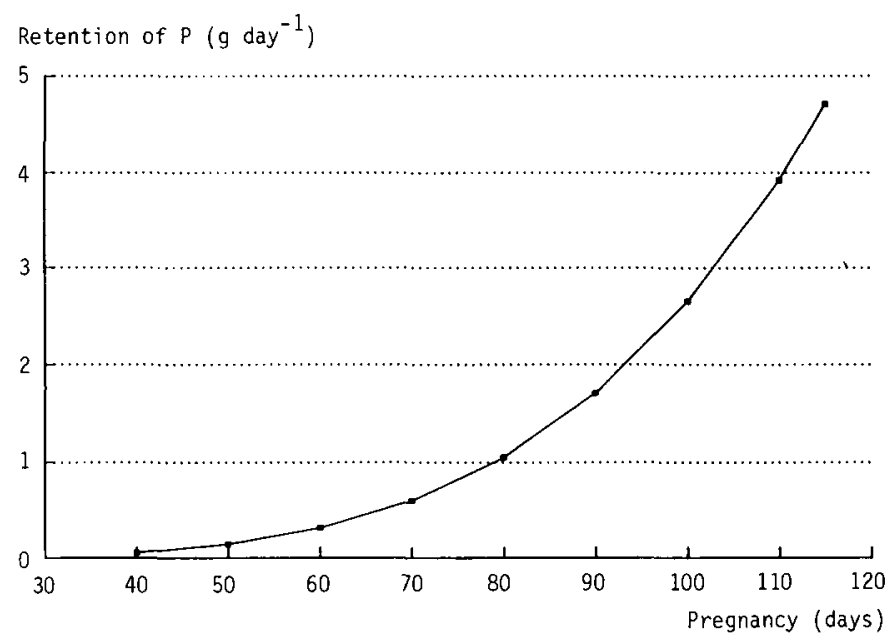

Fig. 1. Retention of $P$ in 12 foetuses during pregnancy (based on Den Hartog et al., 1988). 
Table 5. Estimated $\mathrm{P}$ requirement for dry and pregnant sows ( $\mathrm{g} \mathrm{day}^{-1}, 200 \mathrm{~kg}$ live weight).

\begin{tabular}{lllllllll}
\hline & \multicolumn{9}{l}{ Days of pregnancy } \\
\cline { 2 - 8 } & 0 & 60 & 90 & 100 & 105 & 110 & 115 \\
& 1.4 & 1.4 & 1.4 & 1.4 & 1.4 & 1.4 & 1.4 \\
'maintenance' & 0.6 & 0.6 & 0.3 & 0.2 & 0.2 & 0.1 & 0.1 \\
$\begin{array}{l}\text { extra uterine growth } \\
\text { accretion of P in bones }\end{array}$ & 1.0 & 1.0 & 1.0 & 1.0 & 1.0 & 1.0 & 1.0 \\
$\begin{array}{l}\text { Retention in udder, } \\
\quad \text { uterus and placenta }\end{array}$ & - & 0.1 & 0.2 & 0.4 & 0.6 & 0.6 & 0.6 \\
$\begin{array}{l}\text { retention in 12 piglets } \\
\text { total requirement }\end{array}$ & - & 0.3 & 1.7 & 2.7 & 3.3 & 3.9 & 4.7 \\
$\begin{array}{l}\text { feed intake (kg day } \\
\text { P content of feed }\end{array}$ & 3.0 & 3.4 & 4.6 & 5.7 & 6.5 & 7.0 & 7.8 \\
$\quad(\mathrm{~g}$ dig. P kg & 2.5 & 2.5 & 3.0 & 3.0 & 3.0 & 3.0 & 3.0 \\
\hline
\end{tabular}

Table 5 shows the estimated $\mathrm{P}$ requirement for dry and pregnant sows weighing $200 \mathrm{~kg}$ based on a litter of 12 piglets. According to the Dutch standards (CVB, 1990) $2.5 \mathrm{~kg}$ feed is given in the first 12 weeks of pregnancy and thereafter till farrowing $3.0 \mathrm{~kg}$. The concentration of digestible $P$ in the feed increases from 1.2 $\mathrm{g} \mathrm{kg}^{-1}$ at the start of pregnancy to $2.6 \mathrm{~g} \mathrm{~kg}^{-1}$ at term. Especially during the last two weeks of pregnancy there is a substantial increase in the required dietary concentration. However, one week before farrowing pregnant sows are moved to the farrowing house and the feed for lactating sows will be offered. This means that a dietary content of $2.2 \mathrm{~g}$ digestible $\mathrm{P} \mathrm{kg}^{-1}$ will suffice for pregnant sows, provided during the last week of pregnancy a feed containing a higher concentration of digestible $\mathrm{P}$ is fed.

\section{The requirement of $P$ for milk production}

Milk production in the sow is the major determinant of the $\mathrm{P}$ requirement for lactating sows. To date, the requirement for $\mathrm{P}$ has been derived from the amount of milk produced and its $\mathbf{P}$ content. However, measuring the amount of milk produced is difficult and several assumptions have to be made (Den Hartog et al., 1984; 1987; Noblet \& Etienne, 1986; Goerke, 1979). From these experiments it becomes clear that there is a wide range of milk production per piglet from 700 to $1100 \mathrm{~g} \mathrm{day}^{-1}$. Factors affecting the milk production per piglet are a.o., the amount of feed supplied and its nutrient composition and the number of piglets. Taking into consideration that growth rate of the piglets during lactating is aimed at around $250 \mathrm{~g} \mathrm{day}^{-1}$, a production is required of some $850 \mathrm{~g}$ milk per day. A further complication is to obtain a good estimate of the P concentration in sow's milk. This may vary from 1.2 to $1.7 \mathrm{~g} \mathrm{~kg}^{-1}$, although in the literature a value of $1.55 \mathrm{~g} \mathrm{~kg}^{-1}$ is generally adopted (Guéguen \& Salmon-Legagneur, 1959; Freese, 1958). The $P$ content of sow's milk seems to increase with the stage of lactation 
Table 6. Estimated $\mathrm{P}$ requirement for lactating sows ( $200 \mathrm{~kg}$ live weight; 12 piglets) ( $\mathrm{g} \mathrm{day}^{-1}$ ).

\begin{tabular}{|c|c|c|}
\hline & \multicolumn{2}{|c|}{$P$ requirement $\left(\mathrm{g} \mathrm{day}^{-1}\right)$ based on } \\
\hline & milk production & amount of $\mathrm{P}$ piglets \\
\hline 'maintenance' & 1.4 & 1.4 \\
\hline from catabolized protein & -0.5 & -0.5 \\
\hline in milk $(12 \times 0.850 \times 1.6)$ & 16.3 & - \\
\hline for piglets $(12 \times 1.52)$ & - & 18.2 \\
\hline resorption from bone & - & - \\
\hline total requirement & 17.2 & 19.1 \\
\hline feed intake $\left(\mathrm{kg} \mathrm{day}^{-1}\right)$ & 7.2 & 7.2 \\
\hline$P$ content of feed ( $\mathrm{g}$ dig. $\mathrm{P} \mathrm{kg}^{-1}$ ) & 2.4 & 2.6 \\
\hline
\end{tabular}

(Freese, 1958). For our calculations we assume $1.6 \mathrm{~g} \mathrm{P} \mathrm{kg}^{-1}$ milk. The results of the calculations are presented in Table 6. Due to great uncertainty concerning milk yield and the $P$ content of milk more accurate observations are required or another approach has to be studied.

An alternative approach is to base estimates of requirements for lactation on the quantity of $\mathrm{P}$ in piglets. To obtain a concentration of $5.45 \mathrm{~g} \mathrm{P} \mathrm{kg}^{-1}$ live weight gain (Table 2) and a growth rate of $250 \mathrm{~g} \mathrm{day}^{-1}$, the total requirement both for maintenance and growth by a piglet of $5 \mathrm{~kg}$ live weight can be calculated. The apparent digestibility of $\mathrm{P}$ in milk (skimmed milk powder) is assumed to be $91 \%$ (Jongbloed \& Kemme, 1990). This results in a daily supply of $1.52 \mathrm{~g} \mathrm{P}$ in sow's milk to the piglet (for maintenance and growth). To excrete this amount of $P$ in milk the sow can, apart from $P$ from the feed, rely on catabolism of stored $P$ in the uterus and maternal body. When a total of $1.75 \mathrm{~kg}$ protein is catabolized, this will result in $17 \mathrm{~g}$ available $\mathrm{P}$. Resorption of $\mathrm{P}$ from bones due to a too low feed intake can be compensated by a higher feed intake lateron. However, this contribution is supposed to be minor, and has therefore not been taken into account as a source of $\mathrm{P}$ supply in the milk. The results of the calculations based on the quantity of $P$ in piglets are presented in Table 6 . This Table shows that the amount of $\mathrm{P}$ excreted in milk determines by far most the $\mathrm{P}$ requirement for lactating sows. The total requirement of digestible $\mathrm{P}$ based on the amount of $\mathrm{P}$ in piglets is nearly $2 \mathrm{~g}$ higher than based on milk production. We prefer the estimation of the $\mathrm{P}$ requirement based on the amount of $\mathrm{P}$ in piglets, due to the uncertainties described earlier. Feed intake of sows with 12 piglets was estimated at $7.2 \mathrm{~kg}$ feed (CVB, 1990). From that a concentration of digestible $P$ in the feed of $2.6 \mathrm{~g} \mathrm{~kg}^{-1}$ was calculated. A problem which does arise is that in many cases a high feed intake, such as that recommended by CVB (1990), is not achieved, especially with primiparous sows. When feed intake is $6.5 \mathrm{~kg} \mathrm{day}^{-1}$ instead of $7.2 \mathrm{~kg} \mathrm{day}^{-1}$, then the recommended level in the feed should be $2.9 \mathrm{~g}_{\text {digestible }} \mathrm{P} \mathrm{kg}^{-1}$. Some of the 
$P$ requirements of the piglet can be contributed by the creep feed, although intake of creep feed is low $(0.2-0.5 \mathrm{~kg} / \mathrm{piglet})$ for piglets weaned at 5 weeks of age.

\section{Discussion}

In the preceeding sections the requirement for $\mathrm{P}$ was formulated for animals in various physiological stages. In this section a comparison is made with the recommendations in other countries. First some remarks are made. In contrary to our values expressed as digestible $P$, the others use available $P$ values $(=$ true digestible P). As outlined earlier endogenous losses are $10 \mathrm{mg} \mathrm{kg}^{-1}$ live weight and are therefore $3 \mathrm{mg} \mathrm{kg}^{-1}$ live weight higher than adopted for assessing requirements based on (apparent) digestible P. From this it can be calculated that except for pregnant sows the concentration of available $P$ will be on average $0.05-0.10 \mathrm{~g} \mathrm{~kg}^{-1}$ feed higher than using digestible P. For pregnant sows this is on average $0.25 \mathrm{~g}$ $\mathrm{kg}^{-1}$ feed higher. It should be noticed that the comparison is only proximate due to differences in assumed body weight, feeding level and energy concentration of the feeds.

Table 7 presents a comparison of $\mathbf{P}$ and $\mathrm{Ca}$ requirements for piglets in some other countries with ours. NRC (1988) recommends $3.2 \mathrm{~g}^{2}$ available $\mathrm{P} \mathrm{kg}^{-1}$ feed for pigs of 10 to $20 \mathrm{~kg}$ live weight. The difference in recommended $\mathbf{P}$ concentration compared with ours can be explained by differences in feed intake (0.95 vs 0.71 $\mathrm{kg} \mathrm{day}^{-1}$ ). Guéguen \& Perez suggested $4.0 \mathrm{~g}$ of available $\mathrm{P} \mathrm{kg}^{-1}$ feed for the same range of live weight. The recommendations of ARC (1981) and DLG (1989) are markedly higher than our values. The concentration of $\mathrm{Ca}$ proposed by the NRC (1988) is about $2.0 \mathrm{~g} \mathrm{~kg}^{-1}$ feed lower than by the other recommendations.

Table 8 presents a comparison with recommended $\mathrm{P}$ and $\mathrm{Ca}$ levels in feeds for growing-finishing pigs in some other countries and in our study. The recommendations of NRC (1988) and our study are in a fairly good agreement with each other in the live weight range of 25 to $50 \mathrm{~kg}$. Those of the others are substantially higher. The same can be concluded from 50 to $100 \mathrm{~kg}$ live weight, although NRC (1988) recommendations are lowest of all. However, concentrations are almost equal when the available P concentrations suggested by NRC (1988) are corrected for the difference in feed conversion ratio and energy concentration of the diet compared to our study. The recommended Ca levels in NRC (1988) and in the present study are substantially lower than in the other countries.

It was already indicated that almost maximal bone calcification occurs using the data for growth in Table 2, which is not required for optimal performance of growing animals. Therefore we considered a reduction of the requirement for growth by $0.5 \mathrm{~g} \mathrm{P} \mathrm{kg}^{-1}$ weight gain after $50 \mathrm{~kg}$, possible without harm (Jongbloed, 1987). In that case the concentration of digestible $P$ in the feed can be lowered by $0.15 \mathrm{~g} \mathrm{~kg}^{-1}$.

Comparative values of the $\mathrm{P}$ and $\mathrm{Ca}$ requirement for pregnant and lactating sows in some countries are presented in Table 9. This Table shows that the concentration of available P recommended by NRC (1988) for pregnant sows is much higher than given by the other authors. Our values are almost equal to those 
Table 7. Comparison of available $\mathrm{P}$ and total $\mathrm{Ca}$ requirements of piglets from 10 to $20 \mathrm{~kg}$ live weight as recommended in different countries.

\begin{tabular}{|c|c|c|c|c|c|}
\hline & $\begin{array}{l}\text { NRC } \\
(1988)\end{array}$ & $\begin{array}{l}\text { ARC } \\
(1981)\end{array}$ & $\begin{array}{l}\text { Guéguen \& } \\
\text { Perez (1981) }\end{array}$ & $\begin{array}{l}\text { DLG } \\
\text { (1987) }\end{array}$ & $\begin{array}{l}\text { Present } \\
\text { study }\end{array}$ \\
\hline weight gain (g day ${ }^{-1}$ ) & 450 & - & 450 & 350 & 450 \\
\hline feed intake $\left(\mathrm{g} \mathrm{day}^{-1}\right)$ & 950 & - & 850 & - & 710 \\
\hline feed (MJ ME $\mathrm{kg}^{-1}$ ) & 13.6 & 12.7 & 13.9 & 12.6 & 13.8 \\
\hline available $P\left(\mathrm{~g} \mathrm{~kg}^{-1}\right)$ & 3.2 & $6.6-4.0$ & 4.0 & 5.0 & $3.7^{*}$ \\
\hline total $\mathrm{Ca}\left(\mathrm{g} \mathrm{kg}^{-1}\right)$ & 7.0 & 9.4 & 9.9 & 8.5 & 9.0 \\
\hline $\begin{array}{l}\text { feed conversion } \\
\text { ratio }\end{array}$ & 2.11 & - & 1.9 & - & 1.60 \\
\hline
\end{tabular}

*Digestible $\mathbf{P}$.

Table 8. Comparison of available $\mathrm{P}$ and total $\mathrm{Ca}$ requirements for growing pigs as recommended in different countries.

\begin{tabular}{lccccc}
\hline & $\begin{array}{l}\text { NRC } \\
(1988)\end{array}$ & $\begin{array}{l}\text { ARC } \\
(1981)\end{array}$ & $\begin{array}{l}\text { Guéguen \& } \\
\text { Perez (1981) }\end{array}$ & $\begin{array}{l}\text { DLG } \\
(1987)\end{array}$ & $\begin{array}{l}\text { Present } \\
\text { study }\end{array}$ \\
20 à $25-50 \mathrm{~kg}$ & & & & & \\
weight gain $\left(\mathrm{g} \mathrm{day}^{-1}\right)$ & 700 & - & 650 & 650 & 650 \\
feed intake $\left(\mathrm{kg} \mathrm{day}^{-1}\right)$ & 1.90 & - & 1.7 & - & 1.62 \\
feed conversion ratio & 2.72 & - & 2.6 & - & 2.49 \\
feed $\left(\mathrm{MJ} \mathrm{ME} \mathrm{kg}^{-1}\right)$ & 13.6 & 12.8 & 12.7 & 12.6 & 12.9 \\
available P $\left(\mathrm{g} \mathrm{kg}^{-1}\right)$ & 2.3 & $2.6-4.0$ & 3.3 & 4.0 & $2.4^{*}$ \\
total Ca $\left(\mathrm{g} \mathrm{kg}^{-1}\right)$ & 6.0 & $7.6-9.0$ & 9.2 & 8.0 & 7.0 \\
$50-110 \mathrm{~kg}$ & & & & & \\
weight gain $\left(\mathrm{g} \mathrm{day}^{-1}\right)$ & 820 & - & 830 & 800 & 855 \\
feed intake $\left(\mathrm{kg} \mathrm{day}^{-1}\right)$ & 3.11 & - & 2.6 & - & 2.84 \\
feed conversion ratio & 3.79 & - & 3.1 & - & 3.32 \\
feed $(\mathrm{MJ} \mathrm{ME} \mathrm{kg-1})$ & 13.7 & 12.8 & 12.7 & 12.6 & 12.9 \\
available P $\left(\mathrm{g} \mathrm{kg}^{-1}\right)$ & 1.5 & $1.9-2.6$ & 2.5 & 2.5 & $1.9 *$ \\
total Ca $\left(\mathrm{g} \mathrm{kg}^{-1}\right)$ & 5.0 & $6.2-7.6$ & 8.5 & 6.5 & 5.5 \\
\hline
\end{tabular}

*Digestible $\mathbf{P}$.

of Guéguen \& Perez (1981) and DLG (1987) when corrected for the difference between available and digestible $\mathrm{P}$. There are also great differences in recommended Ca levels for pregnant sows.

The NRC (1988) and DLG (1987) recommended levels for lactating sows are substantially higher than the values recommended in this study. Part of these differences may be due to dietary energy concentrations and feed intake levels, but are also due to differences in the assumed availability of $P$ in the feed. Limited values of $P$ retention during successive cycles of breeding sows are available. More data concerning $\mathbf{P}$ retention during the course of the successive cycles are needed to confirm the data adopted in this study. In this respect limited evidence from 
Table 9. Comparison of available $\mathrm{P}$ and total $\mathrm{Ca}$ requirements for pregnant and lactating sows as recommended in different countries.

\begin{tabular}{|c|c|c|c|c|}
\hline & NRC (1988) & $\begin{array}{l}\text { Guéguen \& } \\
\text { Perez (1981) }\end{array}$ & DLG & $\begin{array}{l}\text { Present } \\
\text { study }\end{array}$ \\
\hline $\begin{array}{l}\text { Pregnant sows } \\
\text { feed (MJ } \mathrm{ME} \mathrm{kg} \text { - }) \\
\text { available } \mathrm{P}\left(\mathrm{g} \mathrm{kg}^{-1}\right) \\
\text { total } \mathrm{Ca}\left(\mathrm{g} \mathrm{kg}^{-1}\right)\end{array}$ & $\begin{array}{r}13.4 \\
3.5 \\
7.5\end{array}$ & $\begin{array}{r}12.7 \\
2.6 \\
10.0\end{array}$ & $\begin{array}{r}12.6 \\
2.6 \\
6.5\end{array}$ & $\begin{array}{c}12.2 \\
2.2^{*} \\
6.0\end{array}$ \\
\hline $\begin{array}{l}\text { Lactating sows } \\
\text { feed (MJ } \mathrm{ME} \mathrm{kg} \text { ) } \\
\text { available } \mathrm{P}\left(\mathrm{g} \mathrm{kg}^{-1}\right) \\
\text { total } \mathrm{Ca}\left(\mathrm{g} \mathrm{kg}^{-1}\right)\end{array}$ & $\begin{array}{r}13.4 \\
3.5 \\
7.5\end{array}$ & $\begin{array}{r}12.7 \\
2.6 \\
7.8\end{array}$ & $\begin{array}{r}12.6 \\
4.0 \\
8.5\end{array}$ & $\begin{array}{c}12.9 \\
2.9^{*} \\
8.5\end{array}$ \\
\hline
\end{tabular}

*Digestible $\mathrm{P}$.

unpublished studies at Lelystad suggested that the $\mathrm{P}$ digestibility coefficients determined in growing pigs are slightly higher than those for multiparous breeding sows. If lower P digestibility coefficients in breeding sows are confirmed in future experiments, then recommendations based on digestible $\mathrm{P}$ for these categories of animals will need to be corrected.

Since introduction of digestible $\mathrm{P}$ for pigs as a criterion for estimating the nutritive value of $\mathbf{P}$ in the Netherlands, the excretion of $\mathbf{P}$ in growing-finishing pigs has decreased substantially from 1200 to $810 \mathrm{~g} \mathrm{pig}^{-1}$ over the entire growingfinishing period. This reduction of more than $30 \%$, results in less environmental pollution per pig (Coppoolse et al., 1990).

\section{Conclusion}

It has been shown that recommendation of $\mathrm{P}$ requirements in the literature and our experiments vary considerably. These differences can partly be explained by energy concentration in the feed, level of feed intake and performance of the animals. It is not always clear from the recommendations in the literature, which criterium of adequacy has been chosen. For growing-finishing pigs for instance the requirement of $\mathbf{P}$ for maximal performance is lower than for maximal bone caicification (Guéguen \& Perez, 1981). Using the factorial approach of $\mathrm{P}$ requirement estimation for maintenance, growth and foetal deposition and lactation gives a better insight in $\mathrm{P}$ requirement. The estimate of the $\mathrm{P}$ requirement for growth in pigs from 5 to $20 \mathrm{~kg}$ in the literature is higher compared to our own data. With regard to pregnant and primiparous sows more insight is needed concerning the course of deposition of $\mathrm{P}$ in maternal tissue (bone included), udder, placenta and uterus during pregnancy. Better knowledge on the digestibility of $P$ in feedstuffs and on the requirement for $P$ of pigs has already resulted in a substantial reduction of $P$ excretion, resulting in less environmental pollution per pig. 


\section{References}

ARC, 1981. The nutrient requirements of pigs. Technical review by an Agricultural Research Council working party. Commonwealth Agricultural Bureaux, Slough.

Becker, K., 1976. Zur heutigen Kenntnis des Stoff- und Energie-ansatzes von Schweinefoeten und von Ferkeln in der frühen postnatalen Entwicklungsphase. Übersichten Tierernährung 4: 167-195.

Coppoolse, J., A. M. van Vuuren, J. Huisman, W. M. M. A. Janssen, A.W. Jongbloed, N. P. Lenis \& P. C. M. Simons, 1990. The excretion of nitrogen, phosphorus and potassium by farm animals, now and tomorrow. (In Dutch). Dienst Landbouwkundig Onderzoek, Wageningen.

CVB, 1990. Feed requirements for farm animals and feeding value of feeds. Short table. (In Dutch). Centraal Veevoederbureau in Nederland, Lelystad.

Dellaert, B. M., G. F. V. Van der Peet, A. W. Jongbloed \& S. Beers, 1990. A comparison of different techniques to assess the biological availability of feed phosphates in pig feeding. Netherlands Journal of Agricultural Science 38: 555-566.

DLG, 1987. Empfehlungen zur Energie- und Nahrstoffversorgung der Schweine, nr. 4. DLG Verlag GmbH, Frankfurt, 153 pp.

Freese, H. H., 1958. Untersuchungen über den Calcium-, Phosphor-, Magnesium- und Stickstoffumsatz des Ferkels in Beziehung zum Wachstum bei Muttermilch und Muttermilchersatz. Archiv für Tierernährung 8: 330-392.

Goerke, R., 1979. Zur Verwertung der umsetzbaren Energie für die Milchbildung bei unterschiedlicher Proteinversorgung des lactierenden Schweines. Dissertation, Göttingen, 73 pp.

Grimbergen, A. H. M., J. P. Cornelissen \& H. P. Stappers, 1985. The relative availability of phosphorus in inorganic feed phosphates for young turkeys and pigs. Animal Feed Science and Technology 13: 117-130.

Guéguen, L. \& E. Salmon-Legagneur, 1959. La composition du lait de truie: Variations des teneurs en quelques éléments minéraux ( $\mathrm{P}, \mathrm{Ca}, \mathrm{K}, \mathrm{Na}, \mathrm{Mg}$ ). Comptes Rendus Academie des Sciences Paris 249: 784-786.

Guéguen, L. \& J. M. Perez, 1981. A re-evaluation of recommended dietary allowances of calcium and phosphorus for pigs. Proceedings of the Nutrition Society 40: 273-278.

Hartog, L. A. den, M. W. A. Verstegen, H. A. T. M. Hermans, G. J. Noordewier \& G. J. M. van Kempen, 1984. Some factors associated with determination of milk production in sows by weighing piglets. Zeitschrift für Tierphysiology, Tierernährung und Futtermittelkunde 51: 148-157.

Hartog, L. A. den, H. Boer, M. W. Bosch, G. J. Klaassen \& H. A. M. van der Steen, 1987. The effect of feeding level, stage of lactation and method of milk sampling on the composition of milk (fat) in sows. Journal of Animal Physiology and Animal Nutrition 58: 253-261.

Hartog L. A. den, T. Zandstra, B. Kemp \& M. W. A. Verstegen, 1988. Chemical composition of intra uterine tissue and mammary tissue in pigs as related to stage of pregnancy. Journal of Animal Physiology and Animal Nutrition 60: 4-7.

Jongbloed, A. W., 1987. Phosphorus in the feeding of pigs. Effect of diet on the absorption and retention of phosphorus by growing pigs. Doctoral Thesis, Wageningen Agricultural University, $343 \mathrm{pp}$.

Jongbloed, A. W. \& P. A. Kemme, 1990. Apparent digestible phosphorus in the feeding of pigs in relation to availiability, requirement and environment. 1. Digestible phosphorus in feedstuffs of plant and animal origin. Netherlands Journal of Agricultural Science 38: 567-575.

Møllgaard, H., 1955. Analyse des Wachstums mittels Differential gleichungen der Partialprozesse des synthetischen Stoffwechsels. Zeitschrift für Tierphysiologie, Tierernährung und Futtermittelkunde 10: $1-25$.

Mudd, A. J., W. C. Smith \& D. G. Armstrong, 1969. The retention of certain minerals in pigs from birth to $90 \mathrm{~kg}$ live weight. Journal of Agricultural Science (Cambridge) 73: 181-187.

Noblet, J. \& M. Etienne, 1986. Effect on energy level in lactating sows on yield and comparison of milk and nutrient balance of piglets. Journal of Animal Science (Cambridge) 63: 1888-1896.

NRC, 1988. Nutrient requirements of swine. Ninth revised edition. National Academy Press, Washington, D.C. 93 pp.

Pointillart, A., N. Fontaine, M. Thomasset \& M. E. Jay, 1985. Phosphorus utilization, intestinal phosphates and hormonal control of calcium metabolism in pigs feed phytic phosphorus: soya bean 
A. W. JONGBLOED AND H. EVERTS

or rapeseed diets. Nutrition Reports International 32: 155-167.

Vemmer, H., 1982. Der Einfluss der Phosphorversorgung auf die intestinale Absorption von Phosphor bei wachsende Schweinen. Zeitschrift für Tierphysiologie, Tierernährung und Futtermittelkunde 47: $220-230$. 